\title{
Reviews
}

\section{ADVENTURE IN VICTORIA LAND}

THE LONELIEST MOUNTAIN. Hall, Lincoln. 1989. Brookvale, NSW, Simon \& Schuster Australia. 232p, illustrated, hard cover. ISBN 0-7318-0051-6. £19.95.

Subtitled 'the dramatic story of the first expedition to climb Mt Minto, Antarctica', this is the story of the BiCentennial Antarctic Expedition 1988, a small-scale privately-sponsored Australian mountaineering party of six climbers led by geologist Greg Mortimer. Its objective was to achieve the summit of Mount Minto (4165 m), highest and loneliest mountain in the Admiralty Range of Victoria Land. Two of the mountaineers, Mortimer himself and Lincoln Hall, author of this book, were professionals with experience on Everest's North Face. The remaining four were all well-tried in mountain craft and in addition combined medical, film-making and photographic experience.

An ex-fishing trawler, the Allan and Vi Thistlethwayte was chartered to transport the expedition to Antarctica, being skippered by Don Richards and a crew of four including one woman, Margaret Werner, who signed on as cook. Lincoln Hall's narrative, which Thomas Keneally in his introduction describes as 'a ripping yarn', is written in a daily journal style with an immediacy that commands the reader's attention throughout.

Departing Sydney on 31 December 1987 the Thistlethwayte's voyage south proved relatively uneventful excepting a case of chronic seasickness and trouble with the vessel's extremely temperamental engine. Cape Hallet, where the climbers planned to make use of the former IGY buildings as base headquarters, was reached on 1 February. On 3 February a skidoo-hauled sled train set off for the Tucker Glacier, the plan being to attack Mount Minto from its north side via the Man O' War Glacier. It was already late in the season and the climbing party needed to be back at base within six weeks to avoid an involuntary overwintering. The loss of the skidoo early in the proceedings put the outcome in some doubt, but by dint of much relaying and depot-laying the mountain was successfully climbed on 18 February and dedicated as 'the cornerstone in an Antarctic World Park'.

On the return a case of dangerous frostbite forced a reluctant decision to accept a helicopter lift to Hallett offered by 'Greenpeace'. By 23 February the climbers were safely on board Thistlethwayte, braving some very dirty weather homeward bound for Sydney. This book contains much of value to any planner of a private expedition to Antarctica, including some informative appendices dealing with organization, food, medicine, photography and navigation. The high price is amply justified by
Jonathan Chester's superbly reproduced photographs. The book is available direct from Cordee, 3a De Montfort St, Leicester LE1 7HD: include $£ 2.50$ for surface postage and packing. (H. G. R. King, Scott Polar Research Institute, University of Cambridge, Lensfield Road, Cambridge CB2 1ER UK.)

\section{MANUAL OF ANTARCTIC HISTORY} CHRONOLOGICAL LIST OF ANTARCTIC EXPEDITIONS AND RELATED HISTORICAL EVENTS. Robert K. Headland. 1990. Cambridge, Cambridge University Press (Studies in Polar Research). 730 p, illus-

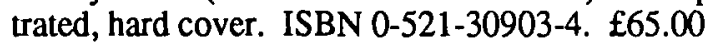

Many years ago Brian Roberts of the Scott Polar Research Institute began compiling lists of Antarctic voyages and expeditions, and found himself unable to stop. A first list published in Antarctic Pilot (1948) was replaced by a fuller one in Polar Record (1958), which remained definitive for many years. Roberts continued to assemble information on Antarctic excursions until his death in 1978, when his papers, including some 800 index cards, passed to SPRI. At the request of the administrators of the B. B. Roberts Fund, Robert Headland took up where Roberts left off, and for several years has been attempting to complete and update the listing. The result at last is this very impressive book.

Headland interprets 'Antarctic voyages and historical events' liberally; his geographical area includes all the Southem Ocean and the peripheral islands, and he has beaten the tussock for his events, creating a long but surprisingly entertaining catalogue. There are $3342 \mathrm{en}$ tries, of which most by far are individual voyages; the rest are happenings of all kinds, some only remotely connected with Antarctic exploration but nevertheless relevant. Data include the year, the occurrence, names of commanders and ships, and brief, informative notes Entry No. 1 is an Phoenician expedition of $\mathrm{c} .700 \mathrm{BC}$ which, according to Herodotus, rounded Cape Agulhas and entered the Indian Ocean, upstaging Bartholomeu Diaz de Novaes by 11 entries and well over 2000 years. No. 9 is a three-line memo of the Venerable Bede, who in 729 postulated not only that the poles were regions of eternal cold, but that the north held a great ocean and the south a great land. The Treaty of Tordesillas gets five lines at No. 14, and the expedition of Fernão de Magalhães (the author is a purist over names) at No. 21 gets well over half a page. Entry 1000 has reached 1869 with the opening of Suez Canal. Entry 2000 covers the 1950 establishment of the Falkland Islands and Dependencies Meteorological Service, and No. 3000 is a brief statement of the 1980-81 annual 